\title{
The Use of Digital Talking Books by People with Print
}

\section{Disabilities: A Literature Review}

Anna Hampson Lundh

Department of Information Studies, School of Media, Culture and Creative Arts, Curtin University, Perth, Western Australia

Swedish School of Library and Information Science, University of Borås, Sweden

Genevieve Marie Johnson, School of Education, Curtin University, Perth, Western Australia

\begin{abstract}
Purpose: The purpose of this paper is to analyse empirical studies regarding the use of digital talking books (DAISY books) as well as the possibilities and limitations that users with print disabilities encounter when using these books. Upon fulfilment of this purpose, it is also possible to identify research needs in the area of talking books.
\end{abstract}

Design/methodology/approach: An analysis of 12 empirical studies concerning the use of DAISY books is conducted. The concept of affordances is employed in the analysis, which focuses on 1) users of talking books, 2) talking books as objects, and 3) the social settings in which talking books are used.

Findings: First, the reviewed literature indicates that the navigational features of the DAISY talking book appear to provide unprecedented affordances in terms of the users' approaches to reading. However, the affordances of talking books depend, to some extent, on whether the users have visual impairments or dyslexia/reading and writing difficulties. Second, the reviewed literature illustrates that the affordances provided by talking books depend on the settings in which they are used, both in terms of specific social situations and wider sociopolitical contexts.

Originality/value: Although the need for assistive reading technologies, such as digital talking books, is large, research in this area is scarce, particularly from a user perspective. This article describes the results of those studies which have actually been conducted on this topic and highlights areas that require further study. 


\section{Introduction}

The ability to open a printed document, such as a book or a magazine, and locate information on a specific page is not generally conceptualised as a special skill. However, for people with print disabilities, this sort of operation is not a given. For people with dyslexia, visual impairments or physical and mobility impairments, the physical act of opening a book, finding a specific entry and then reading that section of printed text may prove difficult or entirely impossible.

However, since the advent of digital talking books in 1994, when the first Digital Accessible Information System (DAISY) prototype was launched, people with print disabilities have been able to access previously elusive text features (DAISY Consortium, 2014a; 2014b; Petri, 2012, pp. 51-53). In addition to, for example, large print, Braille books, and screen magnifiers, the digital talking book is a form of assistive technology for print-disabled readers (Petri, 2012). All talking books include a recorded version of a printed text, but compared to its analogue predecessors, the DAISY talking book offers several additional navigational features, such as flipping between pages, placing bookmarks and using the tables of contents.

The first DAISY format was developed for and launched by the Swedish Library of Talking Books and Braille (TPB, today the Swedish Agency for Accessible Media, MTM), a national library responsible for the production of accessible media for print-disabled people in Sweden (DAISY Consortium, 2014b). The DAISY standard has since been further developed by the DAISY Consortium, formed in 1996 by governmental and non-profit talking book agencies from several countries (DAISY Consortium, 2014a). During its first 20 years, digital talking book technology has developed rapidly. For example, some talking books now include full text which allows sighted users - if their players support this functionality-to use the audio version and the print version of a text concurrently (Petri, 2012, p. 52). In some countries, users can even download talking books directly to their own players, without having to visit a physical library (e.g. Swedish Agency for Accessible Media, 2014). 
While talking books may appear to be similar to audiobooks and, indeed, the two book formats share some basic features, an important distinction exists. The production of talking books for print-disabled users by special talking book agencies is made possible by exceptions in copyright laws. In contrast, because audio books are commercially produced for general use, they must be copyright-compliant. (Roos, 2007; Nilsson, 2008) However, this distinction may eventually become obsolete due to recent developments in e-book publishing that enable electronic texts to be readable in their original formats, with the help of assistive technologies such as synthesised speech (Petri, 2012). Nonetheless, innovative technological solutions will not change individuals' ways of accessing and reading texts overnight. In practice, one format of talking books does not replace another immediately; instead, different versions of talking book formats exist and are used in parallel. Furthermore, the production of and access to the latest talking book formats varies between different countries and languages.

\section{Statement of the Research Issue}

Digital talking book technology is undergoing rapid development, driven largely by stakeholders in the library sector. Changing standards for the production of talking books, the introduction of new ways of accessing them, and the continuous development of hardware and software for using talking books have the potential to change the very ways in which print-disabled users are able to seek, use, and interact with documents. Within the talking book sector, a promising trend can be identified where the difference between print formats and other formats might also become less significant for print-disabled users.

The need for digital talking book technologies is seemingly great. In an overview of accessibility questions in the e-book sector, Ken Petri (2012, p. 42) estimates that at least five percent-possibly up to ten percent-of all Americans have some sort of print disability. However, despite the number of potential talking book users, and despite the technological advances in talking books, at first glance it seems that little basic research has been carried out in this area. Literature regarding talking books appears to be primarily a concern for professional stakeholders and non-profit organisations for the print-disabled, and often from a technology perspective rather than from a user perspective. This was at least the 
impression obtained during the writing of an industry report produced by the first author (Lundh, 2013) on behalf of the Swedish Agency for Accessible Media (MTM). However, no overview of the research exists and, therefore, a first attempt to put together such an overview is made in this article.

The aim of this paper is to analyse empirical studies regarding the use of digital talking books as well as the possibilities and limitations that users with print disabilities encounter when using such books. Upon fulfilment of this aim, it is also possible to identify research needs in the area of talking books. The aim of the study will be achieved through an analysis and discussion of previous literature on talking book use. The analysis is guided by the following four research questions:

According to the analysed literature:

1. Who are the users of digital talking books?

2. How are digital talking books used?

3. In what kinds of situations and settings are talking books used?

4. What affordances do digital talking books seem to provide?

For the discussion on the possibilities and limitations ascribed to digital talking books, the concept of affordances is employed. This concept is discussed in the following section.

\section{Theory of Affordances}

The concept of affordances was introduced by the American psychologist James J Gibson in his work on human perception (e.g. Gibson 1986 [1979]) and has since been used and developed within various fields, such as Human-Computer-Interaction (see Kaptelinin, 2013) and learning research (e.g. Linderoth, 2012; see also Lundh, 2013). In this paper, the concept is understood as the perceived possibilities that arise in the encounter between a person, an object, and an environment. Hence, the usefulness of an object, such as a talking book, is not a consistent factor. Instead, it depends on how people perceive the affordances of the object in a particular physical, social, and historical situation. Thus, a talking book cannot be 
deemed to be useful per se. Its usefulness does not depend solely on its design, the user, or the social and institutional environment in which it is used, but rather on the interaction between these three. The idea is to focus on what takes place between the user and the document within a specific situation.

For this study, the concept of affordances will be used as a way of approaching the reviewed empirical studies. For presentation purposes, the empirical results of the studies will initially be presented as results regarding 1 ) the users of talking books, 2) the talking books as objects, and 3) the social settings in which talking books are used. These three aspects will then be brought together in a discussion on the possibilities and limitations of digital talking books. First, however, the selection of studies will be described.

\section{Studies Reviewed}

The empirical investigations included in the review all examined the manner in which talking books were used by people with print disabilities. Several bibliographical databases were searched, including: Library and Science Abstracts (LISA), Education Resource Information Center (ERIC), ACM Digital Library, IEEExplore, and Google Scholar. Citation chaining (i.e. following citations in the reviewed articles) was also a strategy that was used. The initial approach was to only include scholarly literature published in peer-reviewed journals, but as these kinds of studies proved to be rare, other types of publications, such as a report published by a talking book agency and a Master's thesis, were included. For practical purposes, the studies also had to be published in languages that at least one of the authors understood well.

The original impression of a scarcity of empirical studies about the use of talking books was confirmed by the literature search. In the end, only 12 studies were selected for analysis. About 40 other studies were excluded after a first review. Examples of reasons for exclusion included: (i) studies that reported on other types of recordings of texts, but not on DAISY talking books (e.g. Auld, 2007; Chera and Wood, 2003; Schmidt et al., 2012); (ii) studies that only included talking books on tape (e.g. Murray et al., 1995); (iii) studies focusing on talking 
book providers (Noble, 1996; Tripathi and Shukla, 2014); and (iv) studies about talking book technologies, rather than talking book users and uses (Kimbrough, 2001).

Table 1 provides a list of the studies reviewed. All of the included studies were published after 1994, when the DAISY format was introduced. Most of them only discuss DAISY talking books. However, one study (Miller, 1997) mainly concerns talking books on tape, which were the predecessors of digital talking books. But it also refers to digital assistive technologies that convert written text to other formats. Therefore, this particular study is somewhat of a borderline case, but was included since it provides an exceptional description of how talking book technologies can be used in the everyday life of a young print-disabled person.

\begin{tabular}{|c|l|}
\hline No & Author, year, and title \\
\hline 1. & $\begin{array}{l}\text { Adetoro, N. (2010), "Reading interest and information needs of persons with visual } \\
\text { impairment in Nigeria" }\end{array}$ \\
\hline 2. & $\begin{array}{l}\text { Adetoro, N. (2012), "Alternative format preferences among secondary school visually } \\
\text { impaired students in Nigeria" }\end{array}$ \\
\hline 3. & Getz, I. (2003), "What do blind people want from talking books?" \\
\hline 4. & $\begin{array}{l}\text { Lockerby, C., Breau, R. and Zuvela, B. (2006), "Enhancing digital access to learning materials } \\
\text { for Canadians with perceptual disabilities: a pilot study" }\end{array}$ \\
\hline 5. & $\begin{array}{l}\text { Miller, D.D. (1997), "Encouraging an adolescent daughter who is blind and learning disabled } \\
\text { to read and write" }\end{array}$ \\
\hline 6. & $\begin{array}{l}\text { Morley, S. (1998), "Digital talking books on a PC: a usability evaluation of the prototype } \\
\text { DAISY Playback Software" }\end{array}$ \\
\hline 7. & $\begin{array}{l}\text { Nasmith, W. and Parkinson, M. (2008), "Senior citizens embrace change and make a new } \\
\text { technology work for them" }\end{array}$ \\
\hline 8. & Nes, M.E.S. (2007), Appraising and evaluating the use of DAISY. \\
\hline 9. & Noble, S. (2001), “Using digital talking books in schools: RFB\&D's top project" \\
\hline 10. & $\begin{array}{l}\text { Pors, N.O. (2011), Evaluation of the project "Young people with dyslexia across the country" } \\
\text { in Danish] }\end{array}$ \\
\hline 11. & $\begin{array}{l}\text { Suchato, A., Pongkittiphan, T., Suntornwanitkit, S., Suesattabongkot, N. and Punyabukkana, } \\
\text { P. (2010), "Digital storytelling book generator with customizable synthetic voice styles" }\end{array}$ \\
\hline 12. & $\begin{array}{l}\text { Tazawa, N., Totihara, S., Iwahana, Y., Imai, A., Seiyama, N. and Takagi, T. (2010), "Rapid } \\
\text { listening of DAISY digital talking books by speech-rate conversion technology for people with } \\
\text { visual impairments" }\end{array}$ \\
\hline 1. Studies analysed (full references can be found in the reference list)
\end{tabular}

Table 1. Studies analysed (full references can be found in the reference list)

The low number of studies means that the conclusions of the literature review must be interpreted with caution. One benefit, however, is that the studies can be read and analysed in detail, in a way that is not usually possible in more extensive literature reviews (see e.g. Palmer and Choi, 2014). Furthermore, identifying this lack of studies in the area certainly 
leaves an opening for the argument that further studies are needed. This is something we will return to in the concluding section of this paper.

Another question worth considering is whether studies which have not been designed in relation to any specific theoretical and methodological approaches can be analysed by drawing on a particular theoretical concept. However, as none of the included studies articulate any strong theoretical assumptions, it appears that they lend themselves to an analysis based on the concept of affordances.

\section{Analysis}

In this section, the 12 papers will be presented in greater detail under three headings which correspond to the three previously mentioned aspects of affordances.

\subsection{The Users}

The first research question of this paper concerns the users of talking books. Of the studies that provide more in-depth accounts of the users, four concern people with visual impairments in Nigeria (Adetoro, 2010; 2012), New Zealand (Nasmith and Parkinson, 2008), and the USA (Miller, 1997). 'Niran Adetoro's two survey-based studies give an overview of the reading preferences of adults and students with visual impairments in south-western Nigeria, as well as the format preferences of visually impaired students in the same region. Adetoro's main argument (2010) is that visually impaired people have the same information needs as sighted people, and that it is mainly the need for alternative formats that is specific for visually impaired users. However, an underlying problem regarding social inclusion seems to be implied in Adetoro's (2010) discussion. He also highlights the fact that the younger study participants prefer the talking book format to Braille books. This is further investigated in the later study that only focuses on secondary students (Adetoro, 2012). In this study, Adetoro (2012) argues that the situation for visually impaired youth could be significantly improved through special schools for visually impaired secondary students, larger library collections of talking books and other accessible formats, and investments in Braille education. 
A different picture of the prerequisites for using talking books is found in the New Zealand study of older, visually impaired talking book users (Nasmith and Parkinson, 2008). This study takes as its point of departure the changing demographics of New Zealand, where a large proportion of the population is and soon will be over 65 years old. This is likely to lead to greater demands on the Library of the Royal New Zealand Foundation of the Blind. As part of the library's investment in DAISY talking books, the library tested an online distribution system with a group of users aged between 40 and 93 years (mostly persons aged between 70 and 90 years). The main finding of this study was that participants welcomed the technological changes of the talking book distribution system, as it improved their access to talking books and gave them a stronger sense of independence.

Diane Miller's (1997) article on the use of talking books by people with visual impairments differs from the other studies, as it draws on her personal experiences of raising her daughter who was born without eyes. This paper offers a rare account of how talking books and other assistive technologies can be part of a young blind person's literacy practices. It illustrates an individual's trajectory, her successes and challenges, and highlights that there are many paths to literacy.

Two Scandinavian publications, one that summarises several studies conducted in Denmark (Pors, 2011), and another one concerning Norwegian users (Nes, 2007), focus on a user group that seems to be growing, namely young people with dyslexia/reading and writing difficulties. The Norwegian study (Nes, 2007) mainly discusses the technical design of digital talking books, but also includes two surveys conducted among students and teachers in Norwegian primary and secondary schools. One of the empirical findings of this study was that students with dyslexia and reading and writing difficulties constitute the largest user group among primary and secondary school students. Furthermore, this study showed that some of the functionalities of DAISY talking books that were developed for users with visual impairments are of little use to users whose print disabilities are due to dyslexia/reading and writing difficulties. The Danish studies were commissioned by the national talking book agency, NOTA. Taken together, they provide a nuanced description of the growing user group dyslectic children and youth. They show that this group is diverse, with different 
needs in relation to digital talking books, ranging from non-users to young people using talking books in advanced and sophisticated ways. One of the conclusions from this set of studies that gives cause for concern, according to Niels Ole Pors (2011), is the stigmatisation of young people with dyslexia/reading and writing difficulties in a society where print literacy is the norm.

\subsection{The Object: Hardware, Software, and Document Architecture}

The second research question focuses on how talking books are used. Most of the studies (apart from Adetoro, 2010; 2012; Miller, 1997; Pors, 2011) mainly concern the document architecture of talking books and the significance of different hardware and software for playing DAISY talking books. The earliest of these studies is by Sarah Morley and was published in 1998. The paper presents a usability evaluation of the first software developed for using talking books on a PC. The evaluation was conducted with a small group of visually impaired users and results in a list of recommendations for future software development. In light of today's different kinds of talking book software and hardware, the study illustrates the past 20 years' rapid development in talking book technologies, and highlights the new possibilities of navigating in talking books that the DAISY format introduced.

Also Noble's (2001) preliminary study highlights the improvements that the digital talking book format has meant for users' navigational possibilities. Another pilot study (Lockerby et al., 2006) involves usability tests of a stand-alone player and a PC software for DAISY on CDs. This study engaged 52 users with visual impairments and the results showed that both types of players were deemed useful. Again, the navigational features of digital talking books are highlighted, especially for "educational and work-related materials" (Lockerby et al., 2006, p. 482). These results indicate that different kinds of users might have different navigation needs. In Nasmith's and Parkinson's study (2008) of older users, the capabilities for more freely moving around within documents were not utilised by all participants.

Three of the studies (Getz, 2003; Suchato et al., 2010; Tazawa et al., 2010) concern the audio recordings of digital talking books. Getz (2003) presents a study of some 400 Israeli talking book users and their preferences regarding reading style, the inclusion of more than one 
reader in one single book and the gender of the reader, showing that there is no such thing as 'one type of reading fits all'. The two more recent studies suggest technical solutions to common problems associated with high playback speed (Tazawa et al., 2010) and the synthetic character of automatic synthetic speech (Suchato et al., 2010), respectively. One study, a Master's thesis by Miriam Nes from 2007, covers all of the then-existing features of DAISY. One of this study's main conclusions is that many of the capabilities built into DAISY talking books are not used by the Norwegian students included in the study. Therefore, Nes suggests that one strategy for DAISY talking book development is to identify core features for different groups and improve these, rather than to "keep broadening the DAISY standard" (Nes, 2007, p. 114).

\subsection{The Social Setting}

The third research question concerns the situations in which talking books are used. Half of the studies reviewed provide some insights into the social settings in which the use of talking books takes place. The preconditions for the production, dissemination, and use of talking books seem to differ between countries such as Nigeria (Adetoro, 2010; 2012), New Zealand (Nasmith and Parkinson, 2008), the USA (Miller, 1997), Norway (Nes, 2007), and Denmark (Pors, 2011). It would be reasonable to assume that socio-political conditions impact on the provision of talking books. Adetoro (2010; 2012), Miller (1997) and Pors (2011) each emphasise the impact that print disabilities can have on people's education and employment opportunities. However, none of the studies touches the issue of differences between printdisabled people within a country in relation to different socio-economic groups.

Studies conducted in naturalistic settings (that is, settings that are not set up for the purpose of a specific study) on the use of talking books show that talking books are used in various settings such as homes (Nasmith and Parkinson, 2008), educational environments (Adetoro, 2012), and libraries (Miller, 1997). An important finding is that of Nes (2007), who shows that Norwegian school children mainly use talking books at home, but much less in school. Nes also highlights the lack of user training offered to both children and teachers. Also Pors (2011) emphasises the importance of approaches to the use of talking books in the various 
social settings where young users read, such as schools and libraries, as these approaches might impact on how-or even if-talking books are used.

\section{Conclusions and Discussion}

The studies analysed above have been presented with a focus on the users, the object of the talking books, and social settings, respectively. The fourth research question considers these three aspects together and concerns the affordances of digital talking books as depicted in the reviewed literature. This will be discussed in the first section below. The literature review also draws attention to the shortage of studies on how talking books are used. In the final section of the paper, identified research needs in the area of talking books are presented.

\subsection{The Affordances of Digital Talking Books}

A central idea of the concept affordances is that meaning arises in the intersection between a person, an object, and an environment. Thus, approaching talking books from the point of view of this concept implies that talking books are seen as potentially meaning-making devices. The studies analysed above give some indications as to the possibilities and constraints of talking books in terms of meaning-making.

Firstly, the studies can be said to show that the navigational features of the DAISY talking book seem to offer unprecedented affordances in terms of the users' ways of reading. The introductory description in this article of a reader opening a book and starting to read on any page is now something that talking books afford the user to do-and is also something that users do and appreciate. However, to some extent, the affordances of talking books seem to depend on whether the users have visual impairments or dyslexia/reading and writing difficulties (other potential users are not covered in the previous studies analysed). Some functionalities that were developed with visually impaired users in mind do not seem to offer any affordances to dyslectic users, and vice versa. This raises important questions about further developments of the DAISY format, not least in light of the descriptions of the growing number of young users with dyslexia/reading and writing difficulties. 
Secondly, as expected, the literature illustrates that the affordances of talking books depend on the settings in which they are used, both in terms of specific social situations and wider socio-political contexts. However, it must be remembered that these studies only offer snapshots of different social contexts. Nonetheless, it does seem as though investments in talking book production and dissemination in a country or a region have implications for the actual use of talking books. Also, norms and ideals regarding reading matter for the perceived affordances of talking books. In an environment where the use of talking books is viewed with suspicion by others, their use will be complicated regardless of design. Another important aspect that some of the studies touch upon is the stigma that is associated with reading disabilities. Again, this issue lies on the level of the environment in which talking books may be used, rather than on the technical features of talking books.

Taken together, the studies seem to suggest that talking books have potential as meaningmaking devices, and that the realisation of some of this potential varies between settings and user groups. One consequence of this could be that we may need to reevaluate our perception of the talking book as one type of book. Furthermore, the diversity of user groups, not only in terms of types of disabilities, but also in terms of age, education, socioeconomic status, etc. must be taken into consideration. Again, however, it must be stressed that much work remains in order to nuance and confirm these conclusions.

\subsection{Further Research}

It is no understatement to claim that this review of the literature on the use of digital talking books reveals that little research attention has been directed towards this area. Despite estimates that show that the number of people with print disabilities is significant (Petri, 2012, p. 42), this area appears to lie outside the mainstream of Library and Information Science research. It is only possible to speculate about the reasons for this. One somewhat disheartening interpretation might be that research areas related to non-conventional user groups are perceived as low-status.

A more positive interpretation is that this area offers large possibilities in terms of further research. The existent research in this area suggests that not all of the technology's features 
are used. This highlights the importance of constantly involving actual users with various print disabilities in the design processes, so that non-existent affordances, as well as unintended affordances (see Bomer, 2003) can be uncovered.

The review suggests that the literature on the use of digital talking books is scattered across various fields and in various types of publications. In addition, it also highlights that the philosophical foundation for research on the use of talking books is not particularly strong or being made explicit at this point in time. Thus, it appears as though research on talking books would benefit from further theorising, as well as the raising of more critical questions in relation to the DAISY technology. For example, in the reviewed literature, the division into different user groups seems to be done without much problematisation. For example, questions could be raised about the subject positions that are constructed through the categorisation of people with print disabilities and the presumptions about their needs for assistive technologies (see Tuominen, 1997; Tripathi, 2012).

In conclusion, it can be said that the use of talking book technology and similar assistive technologies has potential as an interesting and important object of study. The existent research in this area raises new questions regarding, among other things, access to information, the materiality of information systems, the development of literacies through the use of multimodal assistive technologies, as well as a range of social-technical issues. These questions are all worthy of further study.

\section{Acknowledgments}

This paper is part of the research project Learning to read talking books: The documentary practices of children with print disabilities, funded by the Curtin Senior Research Fellowship, Curtin University, Perth, Western Australia. The authors would like to thank Keith Hampson and Christine Yates for their valuable suggestions on how to improve earlier versions of this paper. 


\section{References}

Adetoro, N. (2010), "Reading interest and information needs of persons with visual impairment in Nigeria", South African Journal of Libraries and Information Science, Vol. 76, No. 1 , pp. $49-56$.

Adetoro, N. (2012), "Alternative format preferences among secondary school visually impaired students in Nigeria", Journal of Librarianship and Information Science, Vol. 44, No. 2, pp. 90-96.

Auld, G. (2007), "Talking books for children's home use in a minority indigenous Australian language context", Australasian Journal of Educational Technology, Vol. 23, No. 1, pp. 48-67.

Bomer, R. (2003), "Things that make kids smart: a Vygotskian perspective on concrete tool use in primary literacy classrooms", Journal of Early Childhood Literacy, Vol. 3, No. 39, pp. 223-247.

Chera, P. and Wood, C. (2003), “Animated multimedia 'talking books' can promote phonological awareness in children beginning to read", Learning and Instruction, Vol. 13, pp. 33-52.

DAISY Consortium (2014a), “About us”, available at: http://www.daisy.org/about us (accessed 25 April 2014).

DAISY Consortium (2014b), "History: the DAISY project", available at: http://www.daisy.org/history (accessed 25 April 2014).

Getz, I. (2003), "What do blind people want from talking books?", paper presented at the 69th IFLA General Conference and Council, August 1-9, Berlin, available at: http://webdoc.sub.gwdg.de/ebook/aw/2003/ifla/vortraege/iv/ifla69/papers/074e-Getz.pdf (accessed 24 April 2014). 
Gibson, J.J. (1986 [1979]), The ecological approach to visual perception, Lawrence Erlbaum Associates, Hillsdale, N.J.

Kaptelinin, V. (2013), “Affordances”, Soegaard, M. and R.F. Dam (Eds.), The Encyclopedia of Human-Computer Interaction, The Interaction Design Foundation, Aarhus. Available at: http://www.interaction-design.org/encyclopedia/affordances and design.html (accessed 26 April 2014).

Kimbrough, B.T. (2001), "DAISY on our desktops?: a review of LpPlayer 2.4", Library Hi Tech, Vol. 19 , No. 1, pp. 32-34.

Linderoth, J. (2012), "Why gamers don't learn more: an ecological approach to games as learning environments", Journal of Gaming and Virtual Worlds, Vol. 4, No. 1, pp. 45-61.

Lockerby, C., Breau, R. and Zuvela, B. (2006), "Enhancing digital access to learning materials for Canadians with perceptual disabilities: a pilot study", Journal of Visual Impairment \& Blindness, Vol. 100, No. 8, pp. 477-482.

Lundh, A.H. (2013), "Talking books and reading children: children describing their use of talking books", Swedish Agency for Accessible Media, MTM, Johanneshov, available at: http://www.mtm.se/Documents/Logotyp/talkingbooks rapport webb.pdf (accessed 13 August 2014).

Miller, D.D. (1997) “Encouraging an adolescent daughter who is blind and learning disabled to read and write", Journal of Visual Impairment \& Blindness, Vol. 91, No. 3, pp. 213-218.

Morley, S. (1998), “Digital talking books on a PC: a usability evaluation of the prototype DAISY Playback Software", Assets '98, Proceedings of the Third International ACM Conference on Assistive Technologies, April 15-17, 1998, Marina del Rey, CA, USA. ACM, New York, pp. 157-164. 
Murray, J., Huynh, T.T.T. and Williamson, K. (1995), “A needs-analysis survey of users of an audio book library", Journal of Visual Impairment \& Blindness, Vol. 89, No. 2, pp. 161-165.

Nasmith, W. and Parkinson, M. (2008). "Senior citizens embrace change and make a new technology work for them", The Electronic Library, Vol. 26, No. 5, pp. 673-682.

Nes, M.E.S. (2007), Appraising and evaluating the use of DAISY, Master's Thesis, Department of Informatics, University of Olso, available at: https://www.duo.uio.no/handle/10852/9653 (accessed 15 April 2014).

Nilsson, J. (2008), "Talböcker och ljudböcker" ["Talking books and audiobooks"], Nilsson, J. (Ed.) Olika sätt att läsa: om barn med funktionsnedsättningar och deras läsning. [Different ways of reading: on children with disabilities and their reading.] BTJ förlag, Lund, pp. 44-51.

Noble, S. (1996), "Recording for the blind and dyslexic: the development of an internet accessible online catalog", Library Hi Tech, Vol. 14, No. 1, pp. 69-73.

Noble, S. (2001), "Using digital talking books in schools: RFB\&D's top project", Library Hi Tech, Vol. 19, No. 1, pp. 25-28.

Palmer, A. and Choi, N. (2014), "The current state of library open source software research: a descriptive literature review and classification", Library Hi Tech, Vol. 32, No. 1, pp. 11-27.

Petri, K. (2012), "Accessibility issues in E-books and E-book readers", Polanka, S. (Ed.) No shelf required 2: use and management of electronic books, American Library Association, Chicago, pp. 35-60.

Pors, N.O. (2011), Evaluering af projektet "Unge ord-blinde i hele landet", [Evaluation of the project "Young people with dyslexia across the country"], Nota, Copenhagen, available at: http://www.nota.nu/sites/default/files/Evaluering.pdf (accessed 19 November 2012). 
Roos, J.W. (2007), “Libraries for the blind as accessible content publishers: copyright and related issues", Library Trends, Vol. 55, No. 4, pp. 879-916.

Schmidt C, Gorman T.J., Gary M.S. and Bayor A.A. (2012), "Impact of low-cost, on-demand information access in a remote Ghanaian village", Information Technologies \& International Development, Vol. 8, No. 2, pp. 85-100.

Swedish Agency for Accessible Media, MTM (2014), "Legimus.se", available at: http://www.mtm.se/english/About-us/legimusse/ (accessed 26 April 2014).

Suchato, A., Pongkittiphan, T., Suntornwanitkit, S., Suesattabongkot, N. and Punyabukkana, P. (2010), "Digital storytelling book generator with customizable synthetic voice styles", iCREATe '10 5th Rehabilitation Engineering \& Assistive Technology Shanghai, China, July 21 24, 2010, Singapore Therapeutic, Assistive \& Rehabilitative Technologies (START) Centre, Singapore, article no. 45.

Tazawa, N., Totihara, S., Iwahana, Y., Imai, A., Seiyama, N. and Takagi, T. (2010), "Rapid listening of DAISY digital talking books by speech-rate conversion technology for people with visual impairments", Miesenberger, K., Klaus, J., Zagler, W.L. and Karshmer, A.I. (Eds.), Computers Helping People with Special Needs 12th International Conference, ICCHP 2010, Vienna, Austria, July 14-16, 2010. Proceedings, Springer, Berlin Heidelberg, pp. 62-68.

Tripathi, M. and Shukla, A. (2014), "Use of assistive technologies in academic libraries: a survey", Assistive Technology, Vol. 26, No. 2, pp. 105-118.

Tripathi, T.P. (2012), Deconstructing disability, assistive technology: secondary orality, the path to universal access, Doctoral dissertation, College of Arts \& Humanities, University of Central Florida, available at:

http://etd.fcla.edu/CF/CFE0004259/Tripathi_Dissertation_final_submission.pdf (accessed 15 April 2014). 
Tuominen, K. (1997), "User-centered discourse: an analysis of the subject positions of the user and the librarian", Library Quarterly, Vol. 67, No. 4, pp. 350-371. 